International Journal of Social Sciences and Humanities
Available online at http://sciencescholar.us/journal/index.php/ijssh
Vol. 2 No. 3, December 2018, pages: $180 \sim 186$
e-ISSN: 2550-7001, p-ISSN: 2550-701X
https://doi.org/10.29332/ijssh.v2n3.228

\title{
Dilemma on Medical Treatments: Rejection of Medical Treatments by Patients and Elements of Neglect through Perspective of Article 304 of Criminal Law
}

\author{
I Made Wahyu Chandra Satriana ${ }^{a}$
}

Article history: Received 9 April 2018, Accepted: 30 August 2018, Published: 4 December 2018

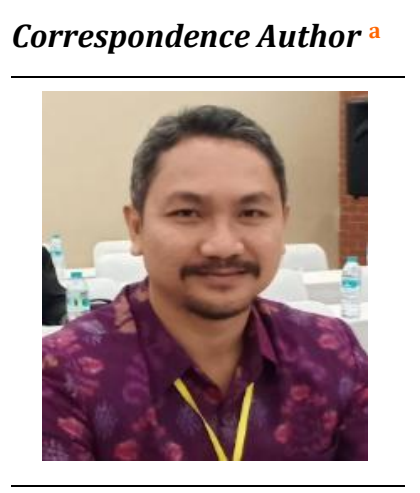

Keywords

article 304;

criminal code;

medical negligence

elements;

rejection medical action;

patient rights;

\begin{abstract}
The right to health care and medical care is a human right that must be respected. No one can abandon patients who need medical treatment and care. Regarding neglect of patients, medical personnel/doctors can be convicted under Article 304 of the Criminal Code. Patients have the right to refuse any type of treatment. There are vague norms in Article 304 of the Criminal Code. The vagueness of the norm lies in the phrase: "placing or leaving someone in a state of misery". The purpose of this paper is to guarantee legal certainty on the vague norms contained in Article 304 of the Criminal Code. The method used in this writing is a normative legal method, the approaches used are the statute approach and historical approach. The results of this study indicate that placing or allowing a patient to refuse medical treatment is not a mistake that is a condition for someone to be convicted. The patient has the right to refuse medical treatment from the doctor after receiving a complete explanation from the doctor based on Law No. 29 of 2004 concerning Medical Practice. Doctors are obliged to respect the rights of the patient, and they do not promise cure patients, but taken great care to treat the patient's illness.
\end{abstract}

e-ISSN: 2550-7001, p-ISSN: 2550-701X ๑ Copyright 2018. The Author. SS Journals Published by Universidad Técnica de Manabí. This is an open-access article under the CC BY-SA 4.0 license (https://creativecommons.org/licenses/by-sa/4.0/) All rights reserved.

\section{Contents}

Abstract 180

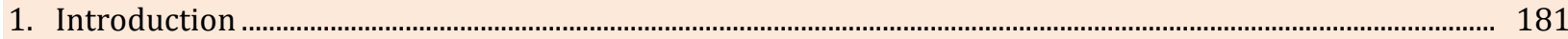

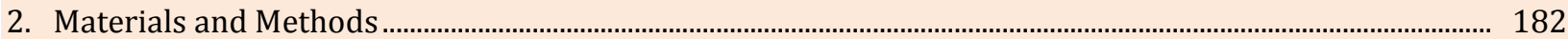

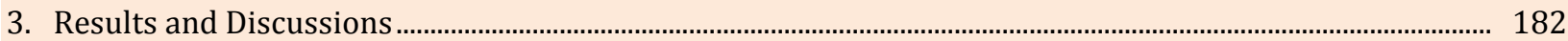

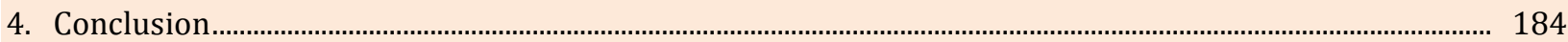

a Universitas Dwijendra, Denpasar, Indonesia 


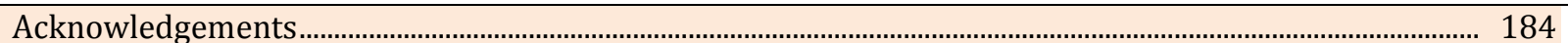

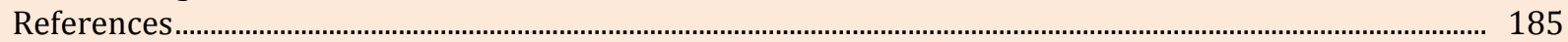

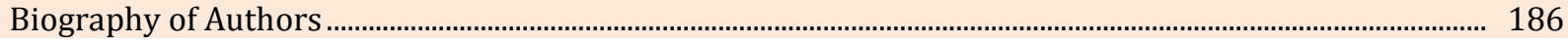

\section{Introduction}

The right to health care and medical care is a human right. The right to health care contained in Article 25 of the Universal Declaration of Human Rights of 1948, among others states:

\footnotetext{
1.Everyone has the right to a standard of living adequate for the health and well-being of him/herself and his/her family, including adequate food, clothing, housing and medical care and necessary social services, and the right to security of life in the event of unemployment, illness, disability, widowhood, old age, or experience a lack of other livelihoods due to circumstances that are beyond his/her control.

2. Mothers and children are entitled to special care and assistance. All children, both born within and outside the marriage, must have the same social protection (Diantha, 2016). ${ }^{1}$
}

Health is absolutely an essential requirement of every human being, without exception, everyone does not want his physical condition to deteriorate and get sick. But in reality the human body is not always fit and healthy, sometimes the condition of the body decreases and eventually get sick. In the terminal stages and near death, patients with chronic diseases not only experience various physical problems such as pain, shortness of breath, weight loss, disruption of activity but also experience psychosocial and spiritual disorders that affect the quality of life of patients and their families (Fitria, 2010). ${ }^{2}$ Every patient wants the disease to be cured. The recovery of patients is the success of doctors in treating their patients. In the development of health science and technology, various sophisticated tools and medicines have been created. Along with advances in health technology, the development of the disease is getting stronger and harder to cure. There are various types of diseases that cannot be cured by health technology or advanced medical science, one of which is cancer.

The American Cancer Society in 2013 stated that the types of cancer most suffered by adults are lung cancer, breast cancer, colorectal cancer, prostate cancer, and skin cancer. While the most common types of cancer suffered by children are leukemia cancer, neuroblastoma cancer, lymphoma cancer, osteosarcoma, wilm tumor, retinoblastoma, and adrenocortical carcinoma (Hardiwardoyo, 1999; Suparna et al., 2018; Banjarnahor \& Samosir, 2017). ${ }^{3}$

The World Health Organization in 2013 stated that cancer incidents increased from 12.7 million cases, in 2008 to 14.1 million cases in 2012. While the number of deaths increased from 7.6 million people in 2008 to 8.2 million in 2012. Cancer is the second leading cause of death in the world by $13 \%$ after cardiovascular disease. It is estimated that in 2030, cancer incidents can reach 26 million people and 17 million of them die from cancer, especially for poor and developing countries, the incidence will be faster. ${ }^{4}$

The Republic of Indonesia guarantees the health of all its citizens. Various health programs have been provided such as the existence of Health Insurance with the establishment of the Health Social Security Organizing Agency (BPJS Kesehatan) to ensure the health of citizens. As an embodiment of Indonesia as a rule of law, various laws and regulations have been made in order to provide protection and guarantee for the best health rights for patients. Law No. 29 of 2004 concerning Medical Practices, in paragraph 7 concerning the Rights and Obligations of Patients in Article 52 states:

Patients receiving care in medical practice, have the right to:

a) get a complete explanation of the medical action as referred to in Article 45 paragraph (3)

b) seek the second opinion of other doctors or dentists;

${ }^{1}$ https://www.ohchr.org/en/udhr/pages/Language.aspx?LangID=inz

2 Fitria, C. N. (2010). Palliative care pada penderita penyakit terminal/ Palliative care in patients with terminal diseases. Gaster| Jurnal Ilmu Kesehatan, 7(1), 527-537.

3 Banjarnahor, S., \& Samosir, J. R. (2017). Hubungan perawatan paliatif dengan kualitas hidup pasien kanker di rumah sakit murni teguh medan tahun 2017/ relationship of paliative care with life quality of cancer patients in murni teguh hospitals of medan in 2017. suwa binusa, 3(02).

${ }^{4}$ Ibid

Satriana, I. M. W. C. (2018). Dilemma on medical treatments: rejection of medical treatments by patients and elements of neglect through perspective of article 304 of criminal law. International Journal of Social Sciences and Humanities, 2(3), 180-186. https://doi.org/10.29332/ijssh.v2n3.228 
c) obtain services according to medical needs;

d) refuse medical treatment; and

e) get the contents of medical records. ${ }^{5}$

Looking at the rights of patients above, there is the right of patients to refuse medical treatment. Rejection of medical treatment by patients will have an impact on the survival of the patient. A doctor in providing disease information to patients must be done carefully and must consider the psychological condition of his or her patients because it can have legal implications. If referring to Article 304 of the Criminal Code which states: "Anyone who intentionally treats or leaves someone in a state of misery, even though according to the law that applies to him/her or because of his/her agreement, is obliged to give life, care or maintenance to that person, can be imposed with imprisonment for a maximum of two years eight months or a maximum fine of four thousand five hundred rupiah." When comparing Article 52 letter d of Law Practice of Medicine with Article 304 of the Criminal Code, as if the medical personnel faced with the dilemma between a patient's right to refuse medical treatment and penalty of neglect. To rectify the dilemma this problem will be examined by normative legal research or doctrinal legal research. ${ }^{6}$ There is a vogue of norms in "putting or letting someone in a state of misery." Putting or letting, is it equal to refusing medical action? The statute approach was done by reviewing all laws and regulations pertaining to the legal issues being addressed. The historical approach was conducted by studying the background of what is learned and the development of the arrangement on the issues encountered (Marzuki, 2017), ${ }^{7}$ so that the problem can be found for its solution.

\section{Materials and Methods}

The research model in the present study is used a qualitative. The theory is adopted based on the regulation belonging in the Indonesian government. The technique of collecting the data is applied to library research. The explanation for each phenomenon is paraphrase descriptively.

\section{Results and Discussions}

The relationship between doctor and patient is a very unique relationship. Doctors as people who provide health services and patients as people who receive health services, doctors who are experts and patients who are lay people, doctors who are healthy and patients who are sick (Lubis \& Harry, 2008). ${ }^{8}$ Doctors will take certain actions based on the knowledge they have to cure their patients. The doctor's actions must be approved by the patient or the patient's family or referred to as Informed consent.

The essence of Informed Consent is a process of communication between patients and doctors. There is a form to be signed by the patient as a realization, affirmation or documentation of what has been agreed upon, where there has been a dialogue between doctors and patients (Guwandi, 2005). ${ }^{9}$ Legal basis where every medical procedure must have informed consent contained in the Minister of Health Regulation number: 585 / MEN.KES / PER/ IX / 1989 concerning Medical Action Agreement, which has been updated with Minister of Health Regulation number 290 / MENKES / PER / III / 2008 of the year 2008. Informed consent is considered something beneficial because it will:

a) increase one's independence;

b) protect patients;

c) avoid fraud and extortion;

d) spur conscientious attitude of doctors and

${ }_{5}^{5}$ Republic of Indonesia Law Number 29 of 2004 concerning Medical Practice.

${ }^{6}$ I Made Pasek Diantha, 2016, Metodologi Penelitian Hukum Normatif dalam Justifikasi Teori Hukum/ Normative Legal Research Methodology in Justification of Legal Theory, Kharisma Putra Utama, Jakarta, page 93.

7 Peter Mahmud Marzuki, 2007, Penelitian Hukum/ Legal Research,Kencana, Jakarta, page 94-95

${ }^{8}$ M. Sofyan Lubis dan Muhammad Harry, 2008, Konsumen \& Pasien dalam Hukum Indonesia/ Consumers \& Patients in Indonesian Law, Liberty, Yogyakarta, page 73.

9 Guwandi. J., 2005, Hospital Law, (Emerging Doktrines \& Jurisprudence).Balai Penerbit UI,Jakarta, page 51 
e) increase community participation. ${ }^{10}$

Approval or a decision in taking medical action by a doctor must be based on ethics. Doctors have an obligation to respect the rights and opinions of patients, decisions taken not only from the wishes of doctors, although doctors know more about the science of disease than patients, the opinions of patients can not be ignored. Doctors must provide information as clearly as possible and then submit decisions to the patient. Doctors are not permitted to persuade, order or advise patients in the interest of doctors. In this case, the patient has the right to self-determination, namely the right to determine his/her own destiny which cannot be contested by anyone including medical experts (Irawan, 2013).11

Law No. 36 of 2009 concerning Health, in Article 56 concerning patient rights to informed consent, states: Paragraph (1): Everyone has the right to accept or reject any or all forms of help that will be given after having received and understood information about such measures in full.

Paragraph (3): The provisions on the right to accept or reject as referred to in paragraph (1) shall be governed by the provisions of the laws and regulations.

Patients undergoing treatment and medication have the rights and obligations as stipulated in Law No. 29 of 2004 concerning Medical Practice, in receiving services in medical practice, in paragraph 7 concerning the Rights and Obligations of Patients;

Article 52 states:

a) Obtaining a complete explanation of the medical actions or treatments as referred to in Article 45 paragraph (3);

b) Seeking for the second opinions from other doctors or dentists;

c) Obtaining services in accordance with medical needs;

d) Refusing medical treatment; and

e) Obtaining the contents of medical records.

Regardless of the type of illness, patients have the right to obtain detailed explanations from the doctors who treat them, regarding the illness suffered by the patients, medical actions taken, and the possibility of healing the patients. For diseases that are classified as mild and easily cured, patients do not need family involvement in decision making. But on the contrary, if the patients suffer from terminal cancer, which has no potential to heal, careful consideration is needed as well as the need for family involvement in making decisions about medical actions to be taken.

Cancer is a process that starts when abnormal cells are changed by genetic mutations from cellular DNA. These abnormal cells are formed and begin to proliferate abnormally, these cells infiltrate the surrounding tissue and gain access to lymph and blood vessels, through these vessels cells can be carried to other areas of the body for metastases (a spread of cancer) in other parts of the body. ${ }^{12}$ There are 4 stages of cancer malignancies, namely stage I, II, III and IV. More specifically, the stages of cancer are divided into stages IA, IB, and IIA, which are called early invasive cancer stages, and stage IIB, stage IIIA-IIIB, and stage IVA-IVB or terminal stages of invasive cancer. ${ }^{13}$

Various physical problems will arise such as pain, shortness of breath, weight loss, disruption of activity but also experience psychosocial and spiritual disorders that affect the quality of life of patients and their families (Sijabat, 2018). ${ }^{14}$ Relating to psychological and social problems faced by patients with terminal illness, Dr. Elizabeth Kubler-Ross identified five stages that may be passed by terminal disease patients, who otherwise would not live much longer, namely:

1) Startled Stage; this stage is usually traversed by terminal illness (terminal'ill). But sometimes they are still shocked and do not believe when are told about their illness or realize the real condition.

2) Rejection stage; at this stage, rejection often occurs not only in sufferers but also by their families.

10 Regulation of the Minister of Health of the Republic of Indonesia Number 749a / MENKES / PER / XII / 1989 concerning Medical Records.

11 Hardiwardoyo Al Purwa, 1999, Etika Dokter/ Doctor Ethics, Kanisius,Yogyakarta, page 19

12 Irawan, E. (2013). Pengaruh perawatan paliatif terhadap pasien kanker stadium akhir/ Effect of palliative care on end-stage cancer patients (literature review). Keperawatan, 1(1).

13 Ibid

14 Sijabat, F. (2018). Relationship of paliative care with the quality of life of cancer patients in h. adam malik public hospital medan in 2016. online journal of indonesian nursing, 1(1), 64-74.

Satriana, I. M. W. C. (2018). Dilemma on medical treatments: rejection of medical treatments by patients and elements of neglect through perspective of article 304 of criminal law. International Journal of Social Sciences and Humanities, 2(3), 180-186. https://doi.org/10.29332/ijssh.v2n3.228 
3) Anger stage; at this stage, the sufferers get angry and often blame the family, medical team, even God or their fate.

4) Stage of depression; sufferers are very passive and some even abandon themselves and even attempt suicide.

5) Resignation stage; in fact, if someone is dying and he/she will get to the stage of resignation. At this stage, if he/she still has physical strength and awareness of thought, there is still hope to improve his/her quality of life (Damayanti, 2008). ${ }^{15}$

Studied from the perspective of criminal law, acts of neglect or omission to the death of a person can be punished. This can be seen from the formulation of Article 304 of the Criminal Code, which states: "anyone who intentionally places or leaves a person in a state of misery, even though according to the law that applies to him/her or because of his/her consent must give life, care or maintenance to that person, is subject to criminal imprisonment of a maximum of two years and eight months or a fine of at most four thousand five hundred rupiah."

Looking at article 304 of the Criminal Code, if the condition of patients suffering from terminal cancer and patients or families refusing medical action to be given by the doctor will have an impact on accelerating the death process of the patient. Doctors can be charged with Article 304 of the Criminal Code because they have agreed to patients and families to stop treatment at the Hospital. Doctors should be able to provide life, care, and treatment to patients. If the doctor does not do this, the patient will eventually die.

In response to this, referring to the medical code of ethics Article 11 of the Indonesian Medical Code of Ethics (KODEKI) 2012 states: Every doctor must always remember his/her obligation to protect human beings. In other words, it can be said that no matter how severe and suffering a patient is, a doctor is still not allowed to take actions that result in ending life or accelerating the death of the patient (Muslich, 2014). ${ }^{16}$ But on the other hand, the Hippocratic view cited by Elliot-Binns states: it is ridiculous to demand doctors for healing efforts that are not made possible by medical science, such as demanding that the body fight an unavoidable disease. Why bother our minds with diseases that cannot be cured / but it is a task of this science to conduct research on them (Kartono, 1984). ${ }^{17}$

One of the phases to be passed by patients with terminal cancer is the stage of rejection. In this stage, the patient or patient's family will refuse medical treatment given by the doctor because it has no impact on the patient's recovery. Patients and families of patients will feel that there is a close physical relationship when treated at home. Patients will feel cared for and not feel isolated from their social interactions. Doctors in dealing with this situation, are obliged to respect the rights of patients as outlined in the legislation. If the patients and their families want them to be treated at home, then the doctors cannot prohibit them and cannot be categorized as neglect of the patients. Patients will feel much more comfortable and calm around the people who love and care for them until death. Doctors do not promise to cure patients but do their best to treat patients' diseases.

\section{Conclusion}

Based on the explanation in the discussion above, it can be concluded that Doctors who approve the patient's desire to refuse medical treatment cannot be convicted under Article 304 of the Criminal Code. Doctors do not neglect these patients, because by refusing medical treatment, patients will get care that is actually better, comfortable, calm, with their beloved family at home. Doctors must respect the rights of patients, one of which is the right to refuse medical treatment. The patient has the right to refuse medical treatment after getting a complete explanation from the doctor about the disease, the action to be taken and the possibility of his/her recovery. This right is regulated in Law No. 29 of 2004 concerning Medical Practice.

\section{Acknowledgments}

The author would like to thank the editor of the International Journal of Social Sciences and Humanities (IJSSH) for their support, valuable time and advice.

15 Damayanti, A. D. (2008). Penanganan masalah sosial dan psikologis pasien kanker stadium lanjut dalam perawatan paliatif/ Handling the social and psychological problems of terminal cancer patients in palliative care. Indonesian Journal of Cancer, 2(1).

16 H. Ahmad Wardi Muslich, 2014, Euthasia Menurut Pandangan Hukum Positif dan Hukum Islam/ Euthanasia in the View of Positive Law and Islamic Law, PT. Raja Grafindo Persada, Jakarta, page 23

17 Kartono Muhammad, 1984, Euthanasia dipandang dari Etik Kedokteran" Makalah pada Simposium Euthanasia/ Euthanasia viewed from Medical Ethics "Paper at the Euthanasia Symposium.. Jakarta, 24 November 1984, page 2-3 


\section{References}

Banjarnahor, S., \& Samosir, J. R. (2017). Hubungan perawatan paliatif dengan kualitas hidup pasien kanker di rumah sakit murni teguh medan tahun 2017. Suwa Binusa, 3(02).

Damayanti, A. D. (2008). Penanganan masalah sosial dan psikologis pasien kanker stadium lanjut dalam perawatan paliatif. Indonesian Journal of Cancer, 2(1).

Diantha, I. M. P., \& SH, M. (2016). Metodologi Penelitian Hukum Normatif dalam Justifikasi Teori Hukum. Prenada Media.

Fitria, C. N. (2010). Palliative care pada penderita penyakit terminal. Gaster/ Jurnal Ilmu Kesehatan, 7(1), 527537.

Guwandi, J., \& Guwandi, J. (2005). Rahasia Medis. Jakarta, Balai Penerbit Fakultas Kedokteran Universitas Indonesia.

Hardiwardoyo, A.P. (1999). Etika Dokter, Kanisius, Yogyakarta.

Irawan, E. (2013). Pengaruh perawatan paliatif terhadap pasien kanker stadium akhir (literature review). Keperawatan, 1(1). https://doi.org/10.31311/.v1i1.84

Kartono, M. (1984). Euthanasia dipandang dari Etik Kedokteran” Makalah pada Simposium Euthanasia. Jakarta, 24 November 1984.

Lubis, M. S., \& Harry, M. (2008). Konsumen \& pasien dalam hukum Indonesia. Liberty Yogyakarta.

Marzuki, M. (2017). Penelitian Hukum: Edisi Revisi. Prenada Media.

Muslich, A. W. (2014). Euthanasia menurut pandangan hukum positif dan hukum Islam. PT. RajaGrafindo Persada.

Sijabat, F. (2018). Hubungan perawatan paliatif dengan kualitas hidup pasien kanker di RSUP H. Adam Malik Medan Tahun 2016. Jurnal Online Keperawatan Indonesia, 1(1), 64-74.

Suparna, I. K., Kumbara, A. N. A., \& Darmika, I. B. (2018). Homeopathy for breast cancer treatment towards Hindu women. International Journal of Health Sciences (IJHS), 2(2), 25-36. https://doi.org/10.29332/ijhs.v2n2.118

Satriana, I. M. W. C. (2018). Dilemma on medical treatments: rejection of medical treatments by patients and elements of neglect through perspective of article 304 of criminal law. International Journal of Social Sciences and Humanities, 2(3), 180-186. https://doi.org/10.29332/ijssh.v2n3.228 


\section{Biography of Author}

\begin{tabular}{|l|l||}
\hline & \\
I Made Wahyu Chandra Satriana is a lecturer in the field of law. He works at \\
Email: wahana.chandra@yahoo.com, wahana.chandra@ gmail.com
\end{tabular}

